\title{
Memecylon cerasiforme (Melastomataceae): a poorly known species rediscovered, redescribed and newly recorded for India
}

\author{
K. Karthigeyan ${ }^{1}$, M. Das Das ${ }^{1} \&$ L.S. Wijedasa ${ }^{2,3,4}$ \\ ${ }^{1}$ Botanical Survey of India, Central National Herbarium, \\ Howrah - 711103, India \\ karthigeyan,murthy@gmail.com \\ ${ }^{2}$ Theoretical Ecology and Modelling Lab, \\ Department of Biological Sciences, \\ National University of Singapore, Singapore 117543 \\ ${ }^{3}$ ConservationLinks, 433, Clementi Avenue 3, \\ \#01-258, Singapore 120433 \\ ${ }^{4}$ Rimba, Kuala Berang 21700, \\ Terengganu, Malaysia
}

\begin{abstract}
The species Memecylon cerasiforme Kurz was previously known only from the type which was collected in Chittagong, Bangladesh. A recent collection of the species from the Jaldapara National Park, West Bengal, India is not only the first since the species was described in 1877 but also the first record of its occurrence in India and the first flowering collection. Its flowers can now be described and illustrated for the first time. An emended description, figure, phenological and habitat information, notes on related species, and a conservation assessment are also provided. The only original material available at Kew is designated here as a lectotype.
\end{abstract}

Keywords. Conservation status, lectotypification, West Bengal

\section{Introduction}

Memecylon L. is a genus of Old World tropical trees consisting of 317-343 described species (Renner et al., 2007; Hughes, 2013). Clarke (1879) enumerated 40 species and 27 varieties of Memecylon in the Flora of British India, of which 14 species and nine varieties were from within the present political boundaries of India. While a number of these species have since been synonymised, the discovery of new species has increased the number of accepted taxa in India to 49 (Das Das et al., 2015). The southern peninsular region of India has been the focus of recent botanical works and accounts for 34 of the currently known species (Manickam et al., 2007; Sivu et al., 2014a, 2014b).

The forests in Northeast India, which are contiguous with Myanmar and northern Thailand, remain relatively underexplored. Currently, six species are known from Northeast India, viz. Memecylon celastrinum Kurz, M. edule Roxb., M. elegans Kurz, M. ovatum Sm., M. plebejum Kurz and M. scutellatum (Lour.) Hook. \& Arn. 
Ongoing taxonomic studies have extended the range of some of these species into Thailand and Indochina (Hughes \& Wijedasa, 2012).

Memecylon cerasiforme Kurz (1877) was described from a specimen from Chittagong in Bangladesh. The description was based on a fruiting specimen. There is a specimen in Kew with the handwriting of Kurz stating 'This is the largest half of the cut specimen at Calcutta'. The other half of the specimen referred to by Kurz could not be traced at CAL. The Kew specimen matches the description provided in the protologue well and is hence designated here as the lectotype of Memecylon cerasiforme.

While carrying out a floristic inventory of the Jaldapara National Park in West Bengal state, India, a population of Memecylon cerasiforme was found. Specimens were collected in fruit in 2013 and in flower the following year.

We supplement the original type description of this poorly known species with characters from the recent collections, especially flower characters which were absent from the original description. The plant is also illustrated. The description is based on recent repeated visits to observe, document and collect specimens from the population of this species in Jaldapara National Park in eastern India. The conservation status of the species is also assessed here.

\section{Taxonomic Notes}

Memecylon cerasiforme Kurz, Forest Fl. Burma 1: 516 (1877). - TYPE: Bangladesh, Chittagong, s.d., Kurz, S. s.n. (lectotype K! [K000357772]), designated here). (Fig. $1-3)$

Tree, 10-15 m high; bole 20-35 $\mathrm{cm}$ in diam.; bark thin, greyish-brown; young branchlets greenish, slightly flattened on 2 sides, grooved in the middle, becoming brown, terete when mature. Leaves opposite, simple, blade elliptic to obovate-elliptic, $6-10 \times 3-4.5 \mathrm{~cm}$, thin-coriaceous, cuneate to attenuate at base, margins entire, longacuminate to caudate-acuminate at apex, acumen 6-10 mm long, dark green, glossy above, pale green beneath, pale green on drying, glabrous, midrib sunken above, raised beneath, lateral veins pinnate, 7-9 pairs, obscure above, faintly visible beneath, regularly spaced, marginal vein faintly visible in dry specimens, $1.5-2.5 \mathrm{~mm}$ from margin. Petioles 5-10 × 1.5-2 mm, glabrous, canaliculate. Inflorescences axillary and terminal, lax, compound cymes, 4-30-flowered; primary peduncles 1-4 at a node, well-developed, 4-angled, 5-13 mm long, elongating in fruits up to $20 \mathrm{~mm}$., 1.5-2 $\mathrm{mm}$ thick, grooved, green, glabrous, secondary peduncles $8-10 \mathrm{~mm}$ long, glabrous; bracts triangular, c. $1 \times 0.8 \mathrm{~mm}$, pale brownish; pedicels $5-8 \mathrm{~mm}$, subterete, pale green, glabrous. Flowers bisexual, buds subglobose, pointed at apex, pale purplish white; calyx funnel-shaped, calyx rim very shallowly 4-lobed, glabrous, $3.5-5 \mathrm{~mm}$ across, lobes c. $1 \times 2.5 \mathrm{~mm}$; internally strongly ridged; petals sub-orbicular, 3.8-4 3.2-3.5 mm, acute at apex, entire along margins, shortly clawed, claw c. $0.5 \times 1 \mathrm{~mm}$, pale purplish-white on inner surface, white on outer surface, fleshy in the middle, 


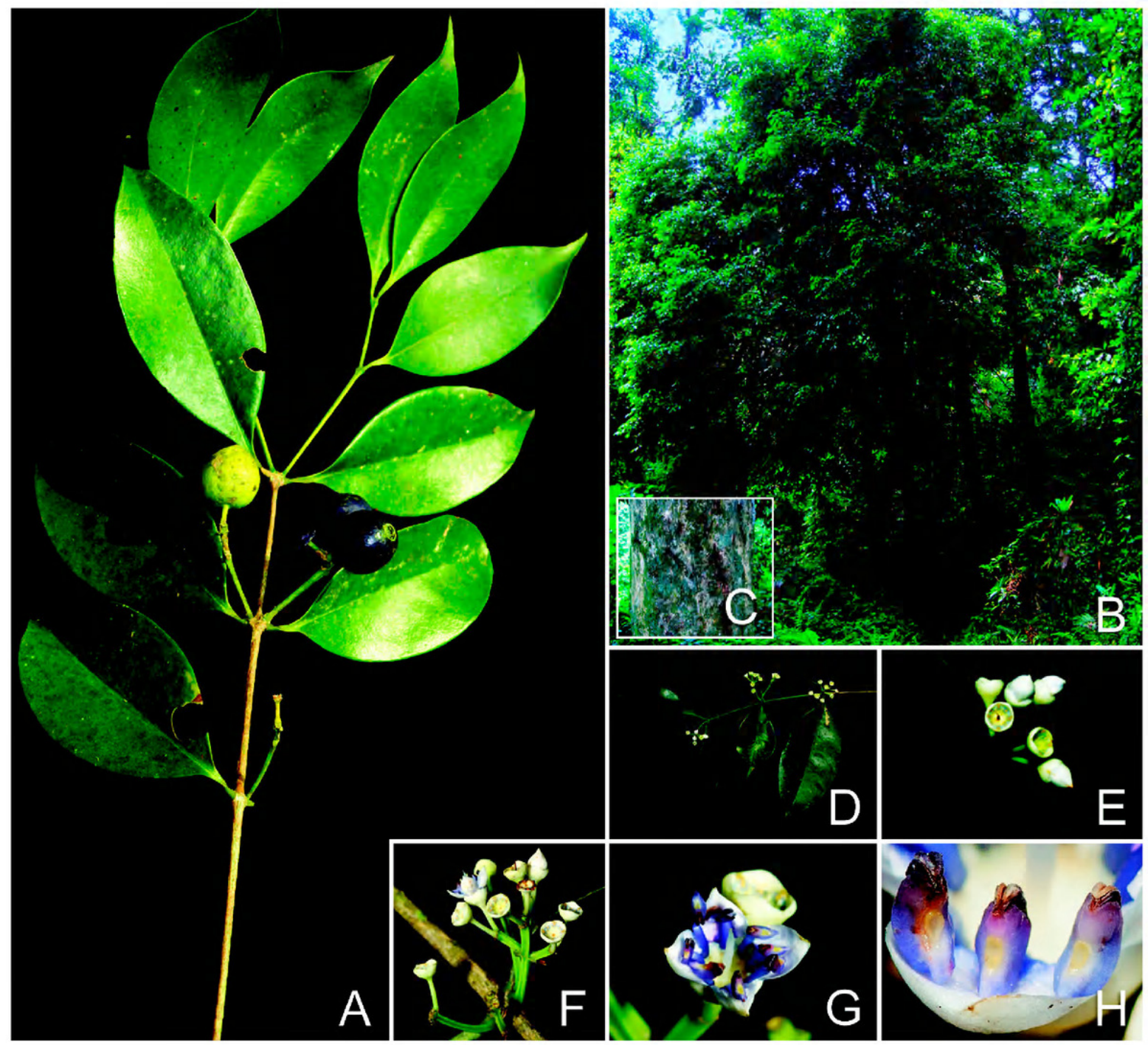

Fig. 1. Memecylon cerasiforme Kurz. A. Fruiting-twig. B. Habit. C. Bark. D. Flowering-twig. E. Close-up of buds. F. Inflorescence. G. Close-up of flower. H. Close-up of anther. (Photos: K. Karthigeyan)

gradually thinning and membranous along margins, glabrous. Stamens 8, equal; filaments subulate, c. $3.5 \times 0.7 \mathrm{~mm}$, glabrous, light blue; anthers 8 , curved, c. $2 \times 1$ $\mathrm{mm}$, with a c-shaped connective, connective purple near anther theca changing to light blue towards lower end, gland yellow, c. $0.7 \mathrm{~mm}$ long, anther theca purple. Ovary unilocular; ovules 10-12, placentation free-central; style subulate, 5-6 $\times 0.4-0.5 \mathrm{~mm}$, pale bluish white, glabrous; stigma white. Berries broadly ovoid to subglobose, 1.2$1.5 \times 1.2-1.4 \mathrm{~cm}$, glabrous, pale green, turning dark blackish purple on ripening, shiny, calyx rim persistent, sunken.

Phenology. Flowering May-June; fruiting February-March. 
Habitat and Ecology. Moist areas of dense semi-evergreen forests in Chilapatha range in the Nalraja Garh area at 60-65 m elevation. The vegetation of this area is classified as sub-Himalayan secondary mixed forests (Champion \& Seth, 1968). This region is at the northern fringe of the state in the foothills of sub-Himalayan mountain belts with a moist tropical climate, an annual rainfall averaging $2942 \mathrm{~mm}$ and mean monthly relative humidity between 69 and 91\%. (Shukla et al., 2014). The other plant species commonly found in this habitat are Dillenia indica L. and Knema erratica (Hook.f. \& Thomson) J.Sinclair.

Provisional IUCN conservation assessment. Critically Endangered (CR B2a,b(ii, iii, iv, v); D), following the IUCN Red List Categories and Criteria Version 3.1 (IUCN, 2012). During the present study, the only known living population of this species in India was documented in Jaldapara National Park with 15 mature individuals and 35 saplings. This population covers an area less than $1 \mathrm{~km}^{2}$. Further it is confirmed that there are no recent collection of the species from the type locality (Chittagong hill tracts, Bangladesh) and no specimens are available in DACB (Sarder Nasir Uddin, Principal Scientific Officer, DACB, pers. comm.). The CR status is due to its continuing decline in $\mathrm{AOO}$, quality of habitat, number of locations or subpopulations and the small number of mature individuals in the population.

Specimens examined. BANGLADESH: Chittagong: Kurz, S. 557 (K! [K000357772]).

INDIA: West Bengal: Jaldapara National Park, Chilapatha forest range, Nalraja Garh, 2 Mar 2013, Karthigeyan, K. 59218 (CAL); ibidem, 11 May 2014, Karthigeyan, K. 65007 (CAL); ibidem, 12 May 2014, Karthigeyan, K. 65027 (CAL).

Notes. Cogniaux (1891) stated that the peduncle of Memecylon cerasiforme is 8 $\mathrm{mm}$ long which corresponds to the only type sheet available at Kew [K000357772]. Kurz (1877) stated that the fruiting peduncle is not above $1 / 2$ in. $(=1.27 \mathrm{~cm})$ long. In most of the specimens from Jaldapara, the peduncle length varies between 5 and 13 $\mathrm{mm}$. The second author, whilst conducting revisionary studies on the genus in India, examined several specimens and found the peduncle length often varying from 0.5 to $1.5 \mathrm{~cm}$ within a single species. It is evident from the account of the genus in Sri Lanka (Bremer, 1979) that in some cases peduncle length varies even from 0 to 10 $\mathrm{mm}$ within a single plant in some species. The pedicel length in the freshly collected specimens slightly exceeds the documented length $(3 \mathrm{~mm}$ by Cogniaux and 1 line/2.1 $\mathrm{mm}$ by Kurz). It can be assumed that Kurz would have described the species based on a limited number of fruiting specimens which might have had shorter pedicels. In all other characters the new collections fit well within the circumscription of Memecylon cerasiforme such as leaf-shape, fruit-size and texture.

In addition to Indian materials the authors have also carefully examined the collections of Memecylon from Myanmar and Bangladesh housed at CAL. The only species which Memecylon cerasiforme is similar to is Memecylon celastrinum Kurz. In the latter, the flower buds are much shorter in size and the petals are very much included in the hypantho-calyx tube with only the apices projecting as a beak in bud. 


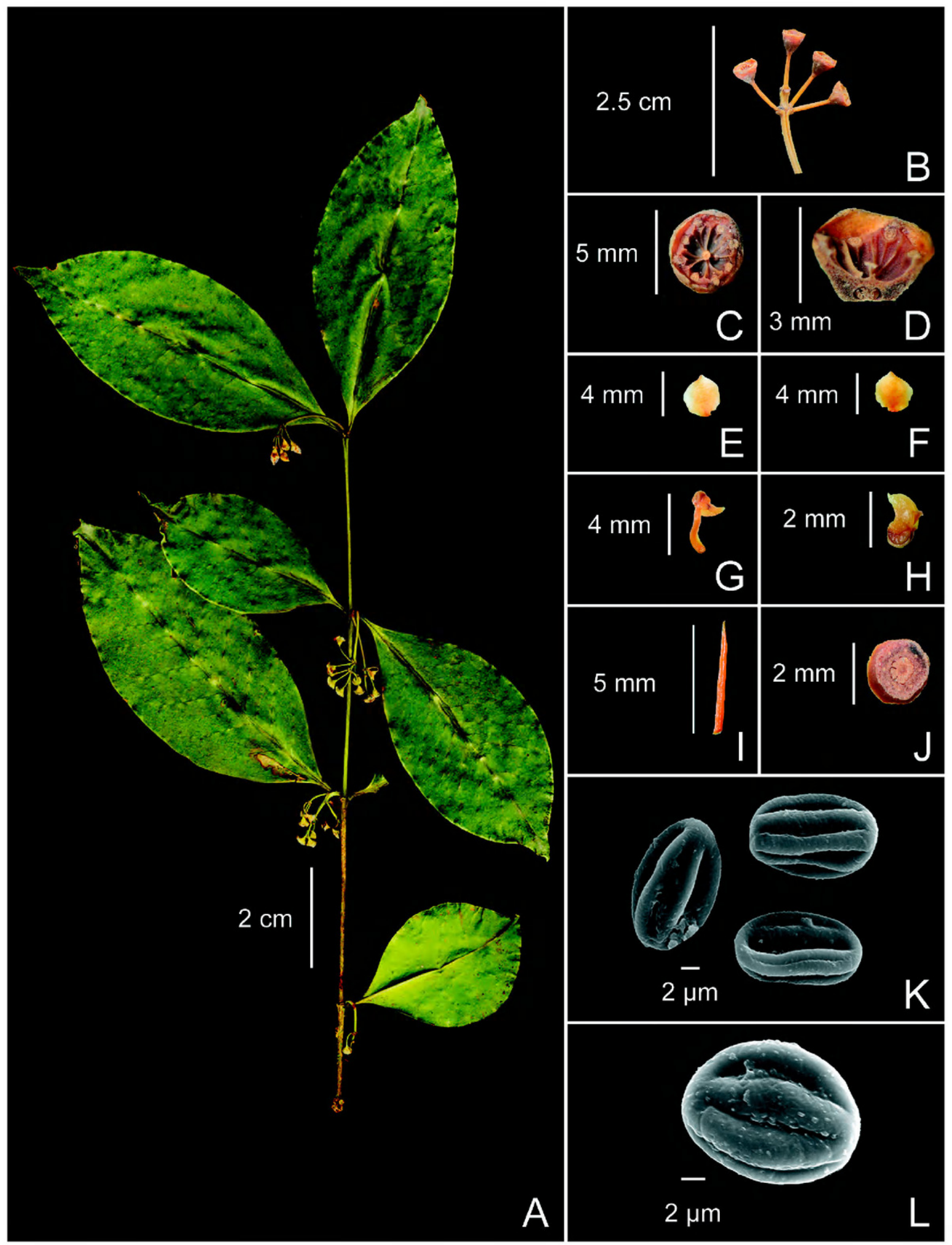

Fig. 2. Memecylon cerasiforme Kurz. A. Flowering-twig (dried material). B. Inflorescence. C \& D. Calyx. E \& F. Petals. G \& H. Anthers. I. Style. J. Ovary (C.S.). K \& L. SEM images of pollen grains. (Photos: K. Karthigeyan) 


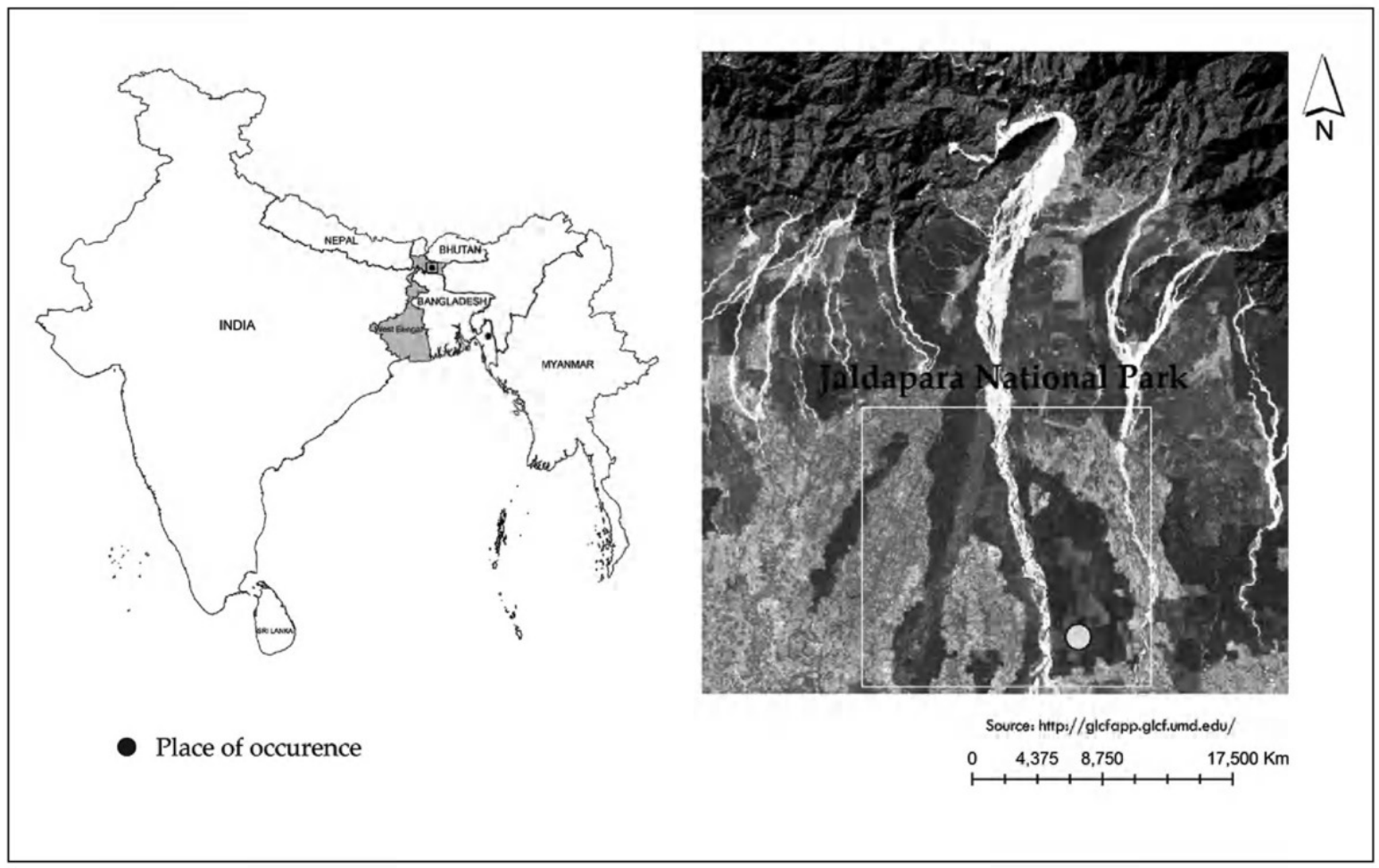

Fig. 3. Distribution of Memecylon cerasiforme in India (Jaldapara National Park, West Bengal) and Bangladesh.

In the recent collection of Memecylon cerasiforme, the buds are larger and the petals are visible throughout their length, except for the basal portion, and they gradually taper to an acute tip. All other taxa occurring in the North-Eastern part of the country and adjacent regions are quite distinct from Memecylon cerasiforme and the newly collected material.

Memecylon celastrinum is vegetatively similar to $M$. cerasiforme although Kurz (1877) states that Memecylon celastrinum has larger leaves than M. cerasiforme. We found these two species could not be distinguished based on a comparison of leaves in herbarium and fresh specimens. These species differ considerably, however, in the size of their flowers and fruits. Memecylon cerasiforme is known to produce larger fruits (up to $2 \mathrm{~cm}$ in diameter) compared to $M$. celastrinum ( $8-10 \mathrm{~mm}$ in diameter). Furthermore, the recent collections of Memecylon cerasiforme from Jaldapara National Park, West Bengal showed that the flowers are apparently larger in size with longer petals $(3.8-4 \mathrm{~mm})$ compared to $M$. celastrinum which has shorter petals $(2-2.25 \mathrm{~mm})$. The present collection of this poorly known species is the first confirmed report of its occurrence from West Bengal. The reports of Memecylon cerasiforme by Kanjilal et al. (1938) and Chauhan (2000) were based on misidentifications of the closely allied species, $M$. celastrinum. Thus, the present collection from Jaldapara National Park is the first authentic record of Memecylon cerasiforme in India. 
ACKNOWLEDGEMENTS. The first and second authors are thankful to Dr Paramjit Singh, Director, BSI, Dr P.V. Prasanna, Scientist ' $F$ ' \& HoO, Central National Herbarium, Howrah (CAL), Dr A. Pramanik, Scientist 'E' \& HoO, A.J.C.B. Indian Botanic Garden, Howrah for facilities and encouragement, and the Principal Chief Conservator of Forest, West Bengal and District Forest Officer, Wildlife Division III, Cooch Behar and Assistant Wildlife Warden, Jaldapara National Park, for their kind permission and support during the survey. Lahiru S. Wijedasa was funded by the Lady Yuen Peng McNiece Graduate Fellowship. We thank Dr Sarder Nasir Uddin, the Principal Scientific Officer at Bangladesh National Herbarium, for information on the specimens at the Bangladesh National Herbarium. The help rendered by $\mathrm{Mr}$ G. Gnanasekaran, MH, Coimbatore, for SEM photograph of pollen, Dr C.R. Magesh, CAL, for preparing maps, Mr K. Dinesh Kumar and Mr A. Balaji, for preparing the photo plate, is thankfully acknowledged.

\section{References}

Bremer, K. (1979). Taxonomy of Memecylon (Melastomataceae) in Ceylon. Opera Bot. 50: $1-32$.

Champion, H.G. \& Seth, S.K. (1968). A Revised Survey of the Forest Types of India. 404 p. New Delhi: Manager of Publications, Government of India.

Chauhan, A.S. (2000). Melastomataceae. In: Singh, N.P., Chauhan, A.S. \& Mondal, M.S. (eds) Flora of Manipur 1.Pp. 389-398. Calcutta: Botanical Survey of India.

Clarke, C.B. (1879). Melastomataceae. In: Hooker, J.D. (ed) The Flora of British India 2. Pp. 512-565. London: L. Reeve \& Co.

Cogniaux, A. (1891). Melastomataceae. In: De Candolle, A. \& De Candolle, C. (eds) Monographiae Phanerogamarum 7. Paris: G. Masson.

Das Das, M., Pramanik, A. \& Maity, D. (2015). Typification of the name Memecylon talbotianum Brandis (Melastomataceae). Phytotaxa 203: 210-212.

Hughes, M. (2013). Memecylaceae. In: Kiew, R., Chung, R.C.K., Saw, L.G. \& Soepadmo, E. (eds) Flora of Peninsular Malaysia, Series II: Seed Plants 4. Kepong: Forestry Research Institute Malaysia.

Hughes, M. \& Wijedasa, L.S. (2012). Memecylaceae of Thailand and Peninsular Malaysia. http://elmer.rbge.org.uk (accessed on 9 Sep. 2014).

IUCN (2012). IUCN Red List Categories and Criteria. Version 3.1 (2nd edition). Gland, Switzerland and Cambridge, UK: IUCN.

Kanjilal, U.N., Kanjilal, P.C. \& Das, A. (1938). Flora of Assam 2. Pp. 305-306. Shillong: Assam Government Press.

Kurz, S. (1877). Forest Flora of British Burma 1. 549 p. Calcutta: Office of the Superintendent of Government Printing.

Manickam, V.S., Murugan, C., Jothi, G.J. \& Sundaresan, V. (2007). Memecylon courtallenseA new species of Melastomataceae from Courtallum hills of Tamil Nadu, India. Indian J. Forest. 30: 77-80.

Renner, S.S., Triebel, D., Almeda, F., Stone, D., Ulloa, C., Michelangeli, F.A., Goldenberg, R. \& Mendoza, H. (2007). MEL names: a Database with Names of Melastomataceae. http://www.melastomataceae.net/MELnames/ (accessed on 22 Dec. 2015).

Shukla, G., Biswas, R., Das, A.P. \& Chakravarty, S. (2014). Plant diversity at Chilapatha Reserve Forest of Terai Duars in sub-humid tropical foothills of Indian Eastern Himalayas. $J$. Forest. Res. 25: 591-596. 
Sivu, A.R., Ratheesh Narayanan, M.K., Pradeep, N.S. \& Shaju, T. (2014a). Memecylon sahyadrica (Melastomataceae), a new species from the Western Ghats, India. Int. J. Advanced Res. 2: 759-763.

Sivu, A.R., Ratheesh Narayanan, M.K., Pradeep, N.S., Santhosh Kumar, E.S. \& Pandurangan, A.G. (2014b). A new species of Memecylon (Melastomataceae) from the Western Ghats, India. Phytotaxa 162: 44-50. 


\section{$2 \mathrm{BHL}$ Biodiversity Heritage Library}

Karthigeyan, K, Das, M Das, and Wijedasa, Lahiru. 2016. "Memecylon cerasiforme (Melastomataceae): a poorly known species rediscovered, redescribed and newly recorded for India." The Gardens' bulletin, Singapore 68(2), 319-326. https://doi.org/10.3850/s2382581216000247.

View This Item Online: https://www.biodiversitylibrary.org/item/223196

DOI: https://doi.org/10.3850/s2382581216000247

Permalink: https://www.biodiversitylibrary.org/partpdf/229557

\section{Holding Institution}

Singapore Botanic Gardens, National Parks Board Singapore

\section{Copyright \& Reuse}

Copyright Status: In copyright. Digitized with the permission of the rights holder. License: http://creativecommons.org/licenses/by-nc-sa/4.0/ Rights: https://biodiversitylibrary.org/permissions

This document was created from content at the Biodiversity Heritage Library, the world's largest open access digital library for biodiversity literature and archives. Visit BHL at https://www.biodiversitylibrary.org. 